\title{
Civil Procedure in Public Interest Litigation: Tradition, Collaboration and the Managerial Judge
}

James Fowkes ${ }^{\text {T }}$

\section{Keywords}

Civil procedure, public interest litigation, managerial judges, Indian public interest litigation

\section{Introduction}

Public interest litigation has been the site of considerable change and creativity in the last forty or fifty years. It must be ranked, over that period, among the most important innovations in the way in which individuals participate in domestic legal systems. This paper seeks to advance the argument that too little attention has been paid in the context of public interest litigation to civil procedure as a positive, sympathetic project.

Procedure was traditionally the device that regulated the role played by individuals in their legal systems. Since this role of individuals has been transformed by public interest litigation, by implication we should also think about a corresponding transformation in procedure. But this is seldom the focus of writing on the topic. Most discussion is concerned with rights and with remedies. When civil procedure is mentioned, it is usually as the target of criticism. It is cast as stale adversarialism, inappropriate in public interest contexts, and as the formal shackles from which litigation seeking substantive justice must break free. Form is supposed to give way to substance; worrying about form, accordingly, is at best pettifogging, at worst a moral abdication, a betrayal.

This paper argues against that grain. One can believe that substance should trump form without necessarily wanting to minimize procedure, because

JSD Candidate, Yale Law School <james.fowkes@yale.edu>. 
procedure (at its best) is concerned with protecting issues of substance. Good procedural rules serve substantive ends like fairness (real and perceived), transparency, predictability, and judicial accountability. Good rules also contribute to the achievement of substantive ends in general, because they are the most obvious way in which a court keeps control of a case and moves it along to its resolution. As we will see, these are all areas of concern for public interest litigation around the world, and in my view this is no coincidence. Problems arise because too little has been done to provide new procedural rules in public interest cases when traditional rules are set aside as inadequate. In an earlier paper, I argue that some of the key problems of India's model of public interest litigation are, in fact, problems of procedure, though they are not always recognized as such 1 ]

Accordingly, it is important to ask whether we can do more to proceduralise (introduce procedure?) into public interest litigation without crippling its ability to respond to problems in non-traditional ways where necessary. Sometimes, flexibility and informality can be uniquely valuable. But given the work that traditional procedure does, we should not be too quick to accept more of its erosion than actually serves the ends of public interest cases. Furthermore, the admitted limitations of formal procedures in some situations do not necessarily mean that we should abandon formal procedures altogether. Such limitations might just indicate that we need new procedures, and I will offer illustrations at the end of the paper of what these might look like. All of this shows why the 'substance over form' injunction is too simple: it begs the question of when sacrificing form is the best means to substantive ends and when it is not.

A further implication of this discussion is that the real procedural question in the public interest context is about when to follow which procedure. In order to help us think about procedural choices here, I offer as a paradigm the idea of the managerial judge, which arose in the US in the 1970s $\mathrm{I}^{2}$ For the managerial judge, formal procedures are always the default-but they are a default to be avoided wherever possible. She is constantly open to flexible, informal methods when they are feasible, but falls back on more formal back-ups when they are not. This paradigm fits a situation where, as I will argue, each of the standard

1 J. Fowkes, 'How to Open the Doors of the Court-Lessons on Access to Justice from Indian PIL', (2011) 27 South African Journal on Human Rights 434, at 458-61.

2 For a summary of the origins, see e.g. R. L. Marcus, 'Malaise of the Litigation Superpower' in A. S. Zuckerman (ed), Civil Justice in Crisis: Comparative Perspectives on Civil Procedure (OUP, 2000) 99, at 102-03. The seminal article is J. Resnik, 'Managerial Judges', (1982) 96 Harvard Law Review 374. 
procedural ideas has something to contribute, though none is entirely adequate on its own. It also shows the need to think about new kinds of formal back-ups.

A final preliminary comment. My primary interest in these questions is practical, but grappling with procedure also yields theoretical insights, and one in particular deserves mention here. Famous articles like Abram Chayes' The Role of the Judge in Public Law Litigation and famous public interest models like India's can make us think of public interest litigation as a unitary phenomenon, as one kind of thing ${ }^{3}$ That is sometimes necessary for the purposes of argument but-as the Indian example shows and as is implicit in Chayes' accoun $t^{4}-$ public interest litigation is a complex and varied phenomenon. Trying to think about its procedural needs is a good way to see that 'public interest litigation' is several things, not one, requiring multiple procedural tools and approaches.

\subsection{An illustration: Indian PIL and procedure}

It is helpful to begin with an example, and Indian PIL, which is as expansive a model as any around and has a comparatively long track record, offers a convenient case. (To avoid confusion, I will follow standard usage and speak of India's model as 'PIL', as distinct from 'public interest litigation' in general.)

Indian PIL began when certain Indian Supreme Court judges in the late 1970s began to take deliberate steps to engage with the problems of the poor. They slashed procedural obstacles, began to take over the work of gathering evidence, and adopted expansionary approaches to interpretation and remedies ${ }^{5}$ All parties were supposed to approach litigation in a collaborative, problemsolving spirit ${ }^{6}$ Judges were supposed to retain jurisdiction until a problem was solved and do whatever was necessary in the way of evidence-gathering, interim orders and the like until that point was reached.

3 A. Chayes, 'The Role of the Judge in Public Law Litigation', (1976) 89 Harvard Law Review 1281, at 1304-5.

4 Since his article is trying to label a new trend, Chayes understandably often talks about public interest litigation as if it were one thing. But he also notes the multiple factors in play, such as 'multiple forms of relief' (Ibid., at 1284, emphasis added) and is hardly blind to the multiple forms the welter of new pressures and devices can take: see e.g. Ibid., at 1313, and A. Chayes, 'The Supreme Court 1981 Term-Foreword: Public Law Litigation and the Burger Court', (1982) 96 Harvard Law Review 4, e.g. at 54.

5 See Fowkes supra note 1 and further sources there cited, esp. at 436 n3, 437-43, 454-55.

6 See e.g. P. N. Bhagwati, 'Judicial Activism and Public Interest Litigation', (1985) 23 Columbia Journal of Transnational Law 561, at 574 and his judgment in SP Gupta v Union of India AIR 1982 SC 149, paras 13-17 on new methods and strategies adopted by the Court to provide access to justice for the disadvantaged. 
It is not too much of an exaggeration to say that PIL procedure can be just what the judge wishes it to be As one might expect, this vast discretion has had mixed results. It permits the sort of flexibility that allows the Supreme Court to run a case like the Right to Food petition, currently approaching its twelfth year of litigation. Since the case began the Court has issued hundreds of interim orders in response to myriad problems associated with a 2001 drought in northeastern Indian and aspects of the government response to it ${ }^{8}$ The case has acquired the status of poster-child, and while inevitably it has its problems, the case demonstrates the virtues of creative procedural responses when a court is confronted with a highly complex, polycentric (and urgent) problem and a persistently inadequate state response to it. But this flexibility also prompts concerns: very procedural concerns that parties are not always receiving an adequate hearing and are having judge-designed settlements forced upon them 9 concerns that fact-finding is insufficiently rigorous and that judgments are showing 'a reliance on unquestioning presumption and reiteration rather than empirical evidence, 10 concerns that PIL today is 'characterised by excessive and overweening judicial power, where judges adopt "command and control" strategies in PIL cases' insufficiently regulated by predictable law and has become politicised as a result ${ }^{12}$ Judges, for their part, express frustration at cases that drag on for years with little or no progress being made ${ }^{13}$ An argument can also be made that the

7 A particularly notable example (which extends outside the PIL context) is the expansive use made by the Indian Supreme Court of Article 142 of the Indian Constitution, which empowers the Court to do what is necessary to do 'complete justice': see A. Chandra, 'Under the Banyan Tree: Article 142, Constitution of India and the Contours of "Complete Justice"” (unpublished manuscript on file with author). I am grateful for her permission to refer to the article, which is still in draft form.

8 PUCL (People's Union for Civil Liberties) v Union of India (Writ Petition (Civil) 196/2001); for key orders, see <http://www.righttofoodindia.org/orders/interimorders.html $>$ [last accessed 22 July 2012].

9 Chandra, supra note 7.

10 V. Iyer, 'The Supreme Court of India' in B. Dickson (ed) Judicial Activism in Common Law Supreme Courts (OUP, 2007) 121, at 122.

11 A. K Thiruvengadam, 'Swallowing a Bitter PIL? Brief Reflections on Progressive Strategies for Public Interest Litigation in India' in S. Narrain \& M. Suresh (eds), The Judicial Nineties (Routledge, forthcoming 2012).

12 See the various criticisms and calls for reform over the years collected by M. Godbole, The Judiciary and Governance in India (Rupa, 2009), at 122-35; B. L. Hansaria \& V. Hansaria, Writ Jurisdiction (Universal Law Pub Co, 2007) at 532-37; B. P. Banerjee, Writ Remedies (Eastern Book Company, 2007) at 1305-08, 1315-16; and Iyer, supra note 10, at 151-52.

13 See e.g. MC Mehta v Union of India AIR 1999 SC 300, para 1-and nearly thirteen years after 
lack of regulation has undermined PIL's ability to expand access to justice ${ }^{14}$

As I will argue in more detail below, PIL reflects the basic procedural challenge posed by public interest cases: the tendency for the problem and the facts, instead of traditional pleadings and procedural rules, to determine the shape and course of the litigation. This open-endedness can be a virtue in some contexts, as we will see, and it can make PIL admirably focused on the real-world problem. But it can also make litigation as hard to define, control and resolve as the problem itself often is, and this inability to give the litigation a defined and predictable shape is reflected in the concerns just cited.

\section{Some procedural models for public interest litigation}

The quick sketch of PIL's problems just offered might mean nothing more than that every scheme has its difficulties and bold ones more than most. A scholar like Sathe is not blind to PIL's faults when he defends it as a justified judicial response to widespread governance failures ${ }^{15}$ It might also simply show that the regulatory demands of the welfare state have outstripped the capacity of traditional court institutions and that we need new ones ${ }^{16}$ These are plausible possible conclusions, but I believe there is room for reform within the traditional institutions if we re-think their rules of procedure.

One possible way to approach this task is to think of public interest litigation as its own distinct kind of litigation requiring its own unique procedural model: a collaborative, problem-solving, complete justice model. This looks especially plausible in the context of the expansive, creative steps sometimes taken in Indian PIL ${ }^{17}$ Other examples suggest different paradigms.

that statement the case has still not been resolved: L. Rajamani \& A. Sengupta, "The Supreme Court of India' in N. G. Jayal \& P. B. Mehta (eds), The Oxford Companion to Politics in India (OUP, 2010) 80, at 87.

14 Fowkes supra note 1, at 451-61.

15 S.P. Sathe, Judicial Activism in India (OUP, 2002), esp. at 249-311.

16 See e.g. B. Ackerman, 'The New Separation of Powers', (2000) 113 Harvard Law Review 633, esp. at 691-93 on the submisison of state bureaucracy to the rule of law; see also B. Ackerman, Reconstructing American Law (Harvard University Press, 1984), at 6-22 on the realist legacy for the legal profession.

17 Indian PIL offers examples, as do some recent Latin American developments - see e.g. M. J. Cepeda-Espinosa, 'Judicial Activism in a Violent Context: The Origin, Role, and Impact of the Colombian Constitutional Court', (2004) 3 Washington University Global Studies Law Review 529; B. M. Wilson, 'Institutional Reform and Rights Revolutions in Latin 
The emerging South African model, which (to the regret of its critics) can be quite cautious in comparison to these other examples, often looks simply like traditional common law adversarialism with some modifications, rather than a new type of litigation ${ }^{18}$ Then again, the suggestion has been made in some common law countries, including the US and India, that public interest litigation represents a step in the direction of the continental model ${ }^{19}$ So we might try to think about public interest procedure as following a continental model with some modifications. This approach is also, naturally enough, a plausible way to think about public interest litigation in continental jurisdictions. For example, Colombia's model, where the Constitutional Court's use of the tutela action created by the 1991 Constitution for the protection of human rights has 'established a solid doctrine of precedent', and so can also be thought of as a modified version of the traditional continental model $\left[{ }^{20}\right.$ I will work through these possibilities in turn.

\subsection{Traditional common law adversarialism and the analogy to private law}

The inadequacies of the common law adversarial model in the public interest context are familiar, but several of the standard points are important to note here. As Chayes famously argued, public interest litigation looks significantly different from bilateral, private dispute resolution. The judge becomes a more

America: The Cases of Costa Rica and Colombia', (2009) 1 Journal of Politics in Latin America 59; C. Rodríguez-Garavito, 'Beyond the Courtroom: The Impact of Judicial Activism on Socioeconomic Rights in Latin America', (2011) 89 Texas Law Review 1669-and some US cases-see Resnik, supra note 2, at 393-95 and sources there cited; O. Fiss, The Civil Rights Injunction (Indiana University Press, 1978). For accounts of the implementation of Brown $v$ Board of Education by the US Circuit courts, a representative example, see e.g. M. J. Klarman, From Jim Crow to Civil Rights: The Supreme Court and the Struggle for Racial Equality (OUP, 2004) at 321-63; J. Bass, Unlikely Heroes (University Alabama Press, 1990).

18 Modifications include regular condonation of procedural violations and some loosening of the rules on new factual evidence (on which see below). For criticism, see esp. the work of Jackie Dugard, most recently J. Dugard, 'Courts and the Poor in South Africa: A Critique of Systemic Judicial Failures to Advance Transformative Justice', (2008) 24 South African Journal on Human Rights 214; see also S. Liebenberg, Socio-Economic Rights: Adjudication under a Transformative Constitution (Juta, 2010) at 43-4, 71-8.

19 See e.g. J. Cooper, 'Public Interest Law Revisited', (1999) 25 Commonwealth Legal Bulletin 135, at 136; Chayes, supra note 3; Fowkes, supra note 1.

${ }^{20}$ See e.g. L. Eslava, 'Constitutionalisation of Rights in Colombia: Establishing a ground for meaningful comparisons', (2009) 22 Revista Derecho del Estado 183; Cepeda-Espinosa, supra note 17 , at 552-54. 
central figure. The fact-finding enquiry becomes concerned with the facts as they really are, rather than simply the version that one party can prove as against the other. The complexity of the problems addressed regularly necessitates engagement with an issue over a period of time. A process that ends with the outcome sought by one party or the other is replaced by an ongoing series of interventions trying to produce a publicly desirable outcome. The legal aim of the litigation is no longer simply 'an increasingly more systematic and refined articulation of the governing legal rules' ${ }^{21}$ Instead, public interest litigation is concerned with producing change in the legal system and/or producing change in the real world.

The differences between public interest litigation and bilateral, private dispute resolution are clear enough, and they also arise in relation to continental model, as we will see. I discuss the procedural consequences of this in relation to both models below. For now, common law adversarialism deserves two arguments in mitigation.

First, whatever else we might say about it, common law adversarialism does represent a carefully refined model for protecting substantive procedural goods and structuring cases, which is a good reason not to give it up unnecessarily. The argument that public interest litigation is not a unitary phenomenon is important here. It reminds us that the failure of traditional methods to handle some kinds of cases is not, without more, a reason to be suspicious of them in public interest litigation generally. It is also relevant that adversarial procedures, whatever their defects, are the system with which common law lawyers are most familiar and which they will most naturally perceive as fair.

The second, related point is that we should be suspicious of any sharp distinctions between public interest litigation and private litigation. The implication of that distinction is that traditional adversarialism fits private bilateralism but not public interest cases, an implication drawn by Chayes in his argument. But Chayes was working on ideal types for the purposes of argument, and was also writing at a time when the distinction between public and private litigation was a lot more plausible than it is today. At that time, $75 \%$ of US civil trials were classical, traditional cases about tort and contract 22 A great deal has changed since. Modern private litigation has expanded into new areas and become much more flexible than the classical picture of bilateral adjudication implies. Public concerns are also increasingly built into

21 Chayes, supra note 3, at 1286.

22 M. Galanter, 'The Vanishing Trial: An Examination of Trials and Related Matters in Federal and State Courts', (2004) 1 Journal of Empirical Legal Studies 459, at 466-73. 
private law enquiries via indirect horizontal constitutional application ${ }^{23}$ In this environment, sharp distinctions are increasingly untenable, and private law adjudication may offer important lessons. This diverse nature of private litigation motivates both my argument against treating public interest cases as a special type of their own, and my proposal to use the managerial judge paradigm, which is mostly applied in the private context-although, in line with this argument, those who study the paradigm use it to refer to a general phenomenon arising across all kinds of cases ${ }^{24}$

\subsection{Traditional continental procedure}

Several features of public interest cases call to mind the continental model: the more central role of the judge, including in appointing experts and seeking evidence; the tendency towards a protracted series of hearings rather than a concentrated trial; and the judicial concern with solving problems, recalling the way continental judges actively seek settlement in a manner traditionally considered anathema by the common law lawyer ${ }^{25}$ Accordingly, it is worth asking whether a modified continental model can serve as a paradigm.

The continental comparison is worth taking seriously. The fact that these traditionally continental features are part of many public interest cases is also a reason why the managerial judge paradigm is helpful: it too contains many of these features ${ }^{26}$ But the analogy between the continental model and public interest litigation is not as strong or as helpful as it might at first appear. It is useful, but it is not the paradigm we need.

There are two main problems with the analogy. The first, which I have discussed elsewhere specifically in the Indian context, is that the court-appointed officers of public interest litigation cannot be equated with court-appointed experts in the continental system. They are not necessarily experts, and their

23 This is an established feature of legal systems such as the Canadian and German systems. It is also a process South African judges are obliged to conduct, see Constitution of the Republic of South Africa, 1996, s 39(2); Carmichele v Minister of Safety and Security 2001 (4) SA 938 (CC), paras 33-41; Shilubana $v$ Nwamitwa 2009 (2) SA 66 (CC), para 48.

24 For example, Judith Resnik notes Chayes' arguments in the public context as part of the trend she is describing mostly in the private one: Resnik, supra note 2, at 377-78, 424-44.

${ }^{25}$ On these common law/continental differences, see e.g. M. Damaska, 'Presentation of Evidence and Factfinding Precision', (1974) 123 University of Pennsylvania Law Review 1083, at 1088-91, 1103-6; Resnik, supra note 2, at 384-86; J. Langbein, 'The German Advantage in Civil Procedure', (1985) 52 University of Chicago Law Review 823, at 826-41 and further sources cited therein.

${ }^{26}$ Resnik, supra note 3, at 425-29; Langbein, supra note 25, at 825, Marcus, supra note 3, at 110-11. 
evidence is not confined to subjects of special expertise: their task may simply be to report what they see happening ${ }^{27}$ As a result, it is not obvious that one can place the same sort of weight on commissioner evidence that is placed on court-appointed expert evidence in a continental system. The problem illustrated by the Indian usage is a general one, because the more a court tackles complex, contested social issues, the more the questions it needs to resolve will tend to expand beyond discrete, objective or scientific ones, and so the less court-appointed persons will look like traditional experts if they are used to help answer them. ${ }^{28}$

The second problem with the analogy is that the factual enquiries of public interest cases can be far more free-wheeling and unfettered than anything in ordinary continental practice. A free-ranging, inquisitorial judge exists in these systems in criminal law. But in civil cases, most continental judges are confined to investigating matters defined by the parties, and those that have a more wide-ranging discretion to shape their own factual enquiries tend to use it narrowly in practice ${ }^{29}$ In practice, the standard continental model is not used to handling the sort of enquiries that public interest litigation can produce. Nor, as I will now turn to argue, can we just 'scale up' continental tools by encouraging judges to use their investigative powers more expansively to match the scope of public interest litigation. The differences, I contend, are of kind and not merely degree. To see this, we need to consider more precisely what it is about (some) public interests cases that makes them not fit traditional models, of either common law or continental varieties.

\subsection{Limitations of traditional theories}

As noted above, I believe that the key procedural challenges that public interest litigation poses relate to the way in which such litigation can erode the traditional means of shaping, controlling and terminating litigation. I make this claim subject to the argument already made, that public interest litigation does not always display these features and does not have a monopoly on them. Nevertheless, to the extent some public interest cases do not fit the traditional models, it is important to understand why those cases do not fit.

On the traditional paradigm, in common law and continental systems alike, an initial pleading stage sets out the legal relief sought. That initial pleading

27 Fowkes, supra note 1, at 458-59.

28 But see below on cases susceptible to resolution by scientific investigation.

29 M. Damaska, 'The Uncertain Fate of Evidentiary Transplants: Anglo-American and Continental Experiments', (1997) 45 American Journal of Comparative Law 839, at 841-43. 
determines what factual questions will need to be answered. Established rules about burdens of proof tell us who must prove what and how we will know when they have succeeded or failed. The link between that enquiry and the initial pleading, in turn, tells us the consequences of that success or failure: the judge gives the relief asked for, throws out the case, or concludes some interlocutory stage. These steps are also fairly rigid. There are stages at which legal issues are defined, after which parties are, exceptions aside, usually held to their legal challenge as pleaded. The same applies to facts, which are determined in retrospective fashion-what happened? - and then adjudicated upon, with new facts generally being inadmissible beyond a certain point at trial, and on appeal ${ }^{30}$ Remedies follow from what was pleaded, and this ends the litigation. This summary glosses over many differences, but it will suffice for present purposes.

Public interest cases can erode every one of these features. The legal form of the dispute will often not be clear in a public interest case where the whole point of the litigation may be to raise a problem for which there is no existing legal solution in order to argue that there should be one. In that situation, the law cannot do the same work to shape the factual enquiry. Instead, it is the facts that are being raised to shape the law. Indian PIL brings this problem out particularly clearly. With its relaxed pleading standards, the PIL petition often serves to do nothing more than raise a factual problem for the court to solve: there is a drought occurring at this place, the government is not responding, and the following problems are resulting. On this sort of fact-only pleading, an argument is made that what is going on cannot be constitutional, but it is up to the court to figure out precisely why. The court is also potentially left to investigate the whole situation, rather than those just aspects of it that are pre-identified by established legal pleadings as facta probanda. Given the complexity of some public interest issues, the result can be a vast enquiry, on which a court can struggle to get purchase. In the Right to Food case, almost any fact relating to the drought or its effects or responses to it looks relevant. (We shall see in a moment how something else was substituted to limit factual enquiries in that case).

The factual enquiry stage of public interest cases is much more open in time

30 Continental systems may permit a first 'appeal' that can amount to a de novo hearing of the case. See e.g. B. Kaplan, A. T. von Mehren \& R. Schaefer, 'Phases of German Civil Procedure (Part II)', (1958) 71 Harvard Law Review 1443, at 1443-4, 1449-51. However, the point will hold good for appeals beyond that, and even at the first appeal, the main task in review de novo is not, however, gathering new evidence, but considering afresh the record and the judgment from below' per Langbein, supra note 25, at 857. 
as well. A court may conduct a fact-finding exercise to investigate a complaint only to discover further violations that may require more investigation. Once the litigation is conceived as an attempt to grapple with the real problem, it is hard to rule new facts out. Without the specific framing of an initial pleading of an established sort, the court has no real basis for saying that the further factual investigation falls outside the scope of the applicant's case.

This openness extends into the remedial stage. The reason is that even if a finding is made about the legal violation, that may not do very much to cut down the factual enquiry. Learning that the lack of adequate government response to the drought in the Right to Food case violates the right to life still does not tell us very much about what to do next-it really just tells us that, indeed, the Constitution does require the problem to be remedied. The scope of the case is as wide as ever, and so the scope of potential fact-finding remains similarly wide open. It is hard to find a principled way to end the remedial stage unless and until some decisive progress is made to solve the problem.

The remedial enquiry is also open in time, too. This is illustrated by a recent decision of the South African Constitutional Court in its first decision on water rights ${ }^{31}$ After going through two lower courts, the government sought to introduce new evidence of its ongoing efforts and adjustments it had made to solve problems, including some that had been brought to light by the litigation. Under the usual approach of the Court , and the traditional approach to appeal, the new evidence would have been inadmissible. But one can see why the Court found it hard to reject. Why make a finding that old facts disclosed a violation and issue a remedy on that basis when the situation had already changed and the state had already responded? The Court created an exception and admitted the evidence 2

A sufficiently detailed account of the right concerned, and the nature and extent of the violation might indeed serve as a basis to define and guide the subsequent remedial activity. But the more one tries to narrow the problem down legally, at an early stage, in order to make it easier to handle, the more one risks having this categorisation undermined by the openness to new facts. Judges will also have incentives to avoid making detailed findings: considerations of minimalism can loom large in public interest cases, which

31 Mazibuko v City of Johannesburg 2010 (4) SA 1 (CC).

32 Ibid., paras 39-41. The exception is ostensibly narrowly crafted and confined to socioeconomic rights cases, but in fact invites a wide-ranging reconsideration of the Court's approach to factual questions, in line with the arguments presented here about problemdefined litigation. Or at least so I contend, and will attempt to show in future work. 
can be complex, politically charged, and raise new or critical questions with potentially vast consequences ${ }^{33}$

It is therefore unsurprising that public interest cases often become lengthy exercises in jurisdiction punctuated by interim orders, without a comprehensive judgment defining the legal violation being issued. The court will often take incremental stabs at the problem, and it is the court, rather than a legal pleading, that continues to define the litigation. Traditional procedures break down here, and without a substitute the work they usually do simply goes undone.

\subsection{The collaborative, problem-solving paradigm}

Is that substitute party co-operation? Some in India insist that PIL 'is' a collaborative, problem-solving form of litigation ${ }^{34}$ The claim that this is what PIL is represents a stronger version of the more common idea that this is what public interest can or should be. For example, in Latin American discussions one finds references, in the public interest context, to the ways in which courts 'may promote a collaborative search for solutions 5 and to ideas of participatory and deliberative democracy ${ }^{36}$ Mazibuko similarly refers to ideas of participation, and speaks of courts as a forum for government reason-giving ${ }^{37}$ As was illustrated by the Right to Food case, adopting a more informal approach can allow courts to engage with a complex, shifting reality. It is, in sum, undeniably appealing to urge everyone to set aside formalities, roll up their sleeves and tackle the problem. Problem-tackling itself erodes procedure; and when this works, it is natural to understand the result as a new kind of litigation, a new role for courts, a new, sophisticated form of democracy in action.

The primary problem with all this, however, is precisely that it is aspirational, and whether these aspirations will be fulfilled is mostly not in the court's control. Basing one's whole model on collaboration means that the model has no answers when parties do not wish to collaborate. When that happens,

33 C. Sunstein, One Case at a Time: Judicial Minimalism on the Supreme Court (Harvard University Press, 1999) at 24-45, on the connection between minimalism and democracy.

34 See e.g. Dr Upendra Baxi v State of UP (1986) 4 SCC 106, 117; Banerjee, supra note 12, at 1305, 1306.

35 Rodríguez-Garavito, supra note 17, at 1695-96.

36 A. Ely Yamin, 'Beyond Compassion: The Central Role of Accountability in Applying a Human Rights Framework to Health', (2008) 10 Health and Human Rights Journal 2, at 6-7; see also R. Gargarella, 'Should Deliberative Democrats Defend the Judicial Enforcement of Social Rights?' in S. Besson \& J.L. Martí (eds), Deliberative Democracy and its Discontents (Ashgate, 2006) 233.

37 See Mazibuko, supra note 31, paras 71, 160, 163. 
the attractiveness of collective problem-solving and democratic participation is greatly diminished. The focus on the problem can become counter-productive. Absent willing parties, the court may be unable to make much progress on the problem, and absent anything other than the problem to shape the litigation, an unsolved problem can mean that there is no principled way to end the case. The risk is litigation as interminable as it is unproductive.

Put another way, the problem is that problem-solving and party cooperation, when they work, are filling in the gaps created by the abrogation of traditional procedures. Progress with the problem takes over the task of defining the steps of the litigation and provides the basis for its ultimate termination. Party co-operation deals with problems like fairness and the allocation of burdens of proof. It signifies consent to informal, ad hoc procedures, and if everyone is collaborating, these problems are less urgent anyway, since they only arise if one is regulating combat. But when parties do not co-operate, and when problems prove intractable, the gaps go unfilled. That does not necessarily prevent the judge from acting. She can override recalcitrant, combative parties, or try to act despite their apathy or inability, and attempt to do the best she can even with a hard problem. But she will then be trying to do these things, and do them in a fair, transparent, judicial manner, in the absence of both the traditional back-and-forth process of adversarial procedure and the deliberative, collaborative processes advocated by the alternative models.

Even the best judges can be expected to struggle in these circumstances, because they are being asked to satisfy demands for procedural goods without a process. The imperative to respond to the problem can lead judges to act expansively, especially if parties are not co-operating. But if judges do act expansively, overriding traditional procedures but also overriding parties' wishes, one has a recipe for unfairness, or the perception of it. Add in the way that public interest cases can produce years of activity without a reasoned judgment, and we can understand how the absence of constraints can make judges a law unto themselves, or make them appear as such, as we saw in the Indian context 38

Collaboration and participation, when forthcoming, also play the procedural role of a checking function. Multiple engaged parties, all scrutinising courses of action from their different standpoints and contexts, can be a functional substitute for the back-and-forth of adversarial pleading (and may be an improvement upon it). But suppose the applicant is a hard-line activist with little interest in compromise, or a grand-standing political figure mostly interested in

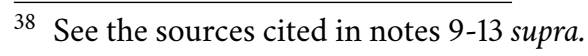


publicity, or a sincere private citizen with very limited means. Suppose that the respondent is a recalcitrant government agency or a disengaged public official. Differing degrees of blame aside, it is unlikely that any of these actors will perform a robust checking function. A great deal will then come to depend on the judge, who may be left to try to appoint experts and committees and otherwise simply be the best philosopher king she can. If the judge herself seeks publicity ${ }^{39}$ or feels urged by the problem-solving imperative to act rapidly, it is easy to see how a court might rush into ill-considered activity based on inadequate facts.

It is important to note two particular aspects of this problem, since certain features of a case can lessen or exacerbate the impact of these difficulties. The first concerns experts. The trite concern in public interest cases is that they are often polycentric ${ }^{40}$ But some polycentric problems are more susceptible of expert resolution than others. Deciding on the size of greenbelts surrounding mines so as to minimize impacts on neighbouring wildlife, residential and tourist areas is a polycentric problem, yet much of the decision-making is about noise levels and dust levels and the distance they travel, and those are all questions with reasonably firm scientific answers ${ }^{41}$ Thus, even if collaboration is not forthcoming in a case like this, there are credible ways for a judge to move the case forward. What effectively happens is that the scientific answer reduces the openness of case. Instead of having to confront the whole problem, the court can focus on implementing the scientific solution. Other polycentric problems, like how to find housing for evicted slum-dwellers or determining the distribution of healthcare resources, do not necessarily have this feature, and the problem of openness will loom much larger in those cases as a result.

Similar narrowing can occur where a court confronts a problem to which government has already enacted a solution, but that solution has proved partially inadequate or has been defectively implemented. The court can focus on reviewing the program and the officials in charge of it, rather than on the problem itself and the universe of possible plans that might be issued in response. It is this feature has narrowed down much of the Right to Food case: the problem of starvation in northeastern India becomes the problem of getting

39 See the acerbic account of certain Indian judges' concern with international human rights prizes by the polemicist A. Shourie, Courts and their Judgments: Premises, Prerequisites, Consequences (Rupa, 2001) at 402.

40 L. Fuller, 'The Forms and Limits of Adjudication', (1978) 92 Harvard Law Review 353, at 394 on the adjudication of polycentric tasks.

41 See MC Mehta v Union of India AIR 1996 SC 1977. 
schemes like the enacted but dormant Mid-Day Meal Scheme implemented $4_{42}^{4}$

I would thus argue that it is no coincidence that Indian PIL has attracted praise in areas where one or both of these conditions are met. For example, environmental cases where the court can draw on scientific expertise, or as Sandra Fredman concludes, 'when the court intervenes to require implementation of policies which have already achieved broad consensus but through apathy, disorganization or failure to prioritize have not been put into action. ${ }^{43}$ It might be too early to draw such conclusions in the Latin American context. But I see it as telling that Colombia's bold moves into healthcare rights, where many cases relate to 'goods and services which the state had already agreed to provide ... and which theoretically should have been financed' seem to have produced fewer problems than Brazil's, where the courts have made orders for novel entitlements ${ }^{44}$ Many factors are in play here, but I contend one of them is the problem of openness.

Bringing the arguments of this section together, we can see how the various problems have an unfortunate tendency to bring out the worst in each other. The more the court struggles to bring a case into focus and determine the conditions for its termination, the more dangerous it is to impose a strong problem-solving imperative. Such an imperative makes it hard for a court to reject or terminate cases on the grounds that they are bad vehicles through which to engage with a problem ${ }^{45}$ Instead, that imperative leads the problem-solving court to take more of the tasks of the litigation upon itself. But the less a problem can be focused by scientific evidence or the presence of an existing program, the more problematic it becomes for the court to do anything without assistance from the ostensibly collaborating parties.

When public interest litigation goes bad, it is because courts have declared problems to be in violation of the constitution, and thus accepted responsibility for fixing them, in circumstances where that is very hard to do and so the responsibility is hard to discharge in any principled fashion. Non-traditional ideas of collaborative and problem-solving adjudication can be very good tools, and a court should be open to these approaches and have the flexibility to try

\footnotetext{
42 For the scheme, see e.g. J. Kothari, 'Social Rights and the Indian Constitution', Law, Social Justice and Global Development Journal (2004), <http://www.go.warwick.ac .uk/elj/lgd/2004_2/kothari> [last accessed 22 July 2012].

43 S. Fredman, Human Rights Transformed: Positive Rights and Positive Duties (OUP, 2008) at 141; see also Fowkes, supra note 1.

44 Yamin, supra note 35, at 7; O. L. Motta Ferraz, 'The Right to Health in the Courts of Brazil: Worsening Health Inequities?', (2009) 11(2) Health and Human Rights 33.

45 For the role this sort of test in PIL, see Fowkes, supra note 1, at 446-47, 452-56.
} 
them. But it is dangerous to rely on them.

\subsection{The managerial judge}

The analysis set out above suggests that we need a model for public interest litigation that can draw on different ideas in different cases, and this is what prompts the proposal to draw on the paradigm of the managerial judge. The idea of judicial management originating in the US, describes the trend toward judges 'not only adjudicating the merits of issues presented to them by litigants, but also ... playing a critical role in shaping litigation and influencing results', with a judge being 'assigned a case at the time of its filing and assum[ing] responsibility for shepherding the case to completion. ${ }^{46}$ The managerial judge is called upon to run trials in accordance with traditional common law adversarial rules, but also to conduct novel tasks that break with that approach. Managerial judges supervise preparation for trial and actively pursue settlement, meeting with the parties informally to do this. Evidence is produced by the regulated mechanism of discovery, but the interrogation of that material is mainly done on an informal, ongoing basis as it informs negotiations and the judges and parties calculations about settlement, rather than at the trial. The judge's role is more in the continental mould and investigative, and she draws on a variety of experts and other actors to assist her. As the number of cases resolved at the pre-trial stage continues to rise, this more informal process usually represents the totality of the litigation in the US. ${ }^{47}$

The parallels between such a judicial role and the situations we have seen that can arise in the public interest context should be manifest. It should be added that similar concerns arise due to the abrogation of traditional procedures, the extent to which the litigation is conducted outside standard rules, and the decline in judges being 'required to reason in public about their decisions to validate one side of the dispute. ${ }^{48}$ Here too, democratic participation is an aspiration not always achieved ${ }^{49}$ The managerial judge is a paradigm, not a panacea. It is simply a useful way to think about the judicial role and procedure in a situation where, in order to respond to extraneous

\footnotetext{
${ }^{46}$ Resnik, supra note 2, esp. 376-78; see also the sources she cites therein in notes 14-15.

47 See e.g. Galanter, supra note 22.

${ }^{48}$ J. Resnik, 'Managerial Judges, Jeremy Bentham and the Privatization of Adjudication' in J. Walker \& O. G. Chase (eds), Common Law, Civil Law and the Future of Categories (LexisNexis, 2010) 205, at 209; see also J. Resnik, 'Managerial Judges: The Potential Costs', (1985) 45 Public Administration Review 686.

49 Resnik, 'Privatization', Ibid., at 218, 223
} 
pressures and serve extraneous ends, new informal procedures arise where traditional formal ones do not fit. Like problem-solving litigation, it is focused on identifying and taking whatever procedural steps will satisfactorily resolve the litigation, rather than being tied to a pre-defined series of formal steps. As such, the managerial judge is always open to the possibility of proceeding in a collaborative manner where the parties can be persuaded to do this. However, unlike these models, the managerial judge always operates against the backdrop of formal procedures: if you cannot negotiate a solution, then the rules are applied and the case goes to trial.

The concept of the managerial judge stands in deliberate counterpoint to the idea that the judge should just focus on the substance and forget the form, but it is also not blind to the value that flexibility and collaboration can have. It focuses judicial attention on constantly defining how litigation should proceed and how it can be satisfactorily resolved. It hardly solves all problems, but it does offer an already well-researched starting point for thinking more carefully about procedure in the public interest context.

An illustration may assist here. Consider a PIL case like Bandua Mukti Morcha, which concerned bonded labour 50 The case began with a letter petition. An advocate was dispatched to confirm its contents, after which a commissioner conducted a more detailed enquiry. One could use this report as a basis for trying to move rapidly to solve the problem. But if we adopt the perspective of the managerial judge, we might instead be inclined to proceed in a way that keeps both informal and formal procedural options open. We could treat the letter plus the advocates initial report fleshing out its factual averments as if they were an initial pleading from the plaintiff. The judge could then hold a meeting of the parties to solicit their engagement with the petition, to get a sense of stances and explore opportunities for collaboration. On the basis of that hearing, the judge could determine how to proceed. If the parties can be convinced to collaborate, then they can broadly accept the founding affidavit and/or constructively supplement it. If, on the other hand, they cannot be so convinced, then the judge can fall back on the standard adversarial procedure and require answering pleadings, from which the judge can determine what disputes of fact exist and proceed in the ordinary way ${ }^{51}$ The meetings will also

50 Bandhua Mukti Morcha $v$ Union of India AIR 1984 SC 802.

51 It is true that a more formal procedure raises problems of expense for poor litigants. The scenario sketched assumes that the court has appointed people to advance the aspects of the case that the applicant cannot, as happened in Bandhua, ibid., or that civil society actors can play this role. To the extent that this does not happen, a managerial judge would need to take the position of poor litigants into account-but, as argued in this paper, it is far from 
provide an opportunity to explore opportunities for collaboration and to see whether the problem displays the sort of helpful narrowing features discussed above. This permits the judge to make early decisions about how to approach the litigation, as well as deciding whether it is likely to be productive to take it to trial at all. She does not have to wait until a violation has been found and the court is committed.

\subsection{New formal procedures for public interest problems: two sketches}

Just as in other cases where special needs arise and special procedural vehicles are designed to meet them-for example, habeas corpus or class actions-the same can be done to deal to meet the needs of public interest litigation. I confine myself to two brief illustrations.

Public interest courts that engage with failures by the government to deal with complex, open-ended problems-like the Right to Food petition or the Forestry Case in the Indian contex $t^{52}-$ can end up like a substitute government, co-ordinating responses to the issue. These cases in fact look a great deal like the situation in which a company is placed under administration. If a company's management fails dramatically, the court can take over the administration of the company to protect other interested parties. Formal procedures govern this process. Something similar can be envisioned for cases of systemic government failure like the aforementioned examples. The issue can be put, temporarily, under judicial management (or, as in the forestry case, in the hands of a court-appointed committee, analogous to a curator) ${ }^{53}$ The analogy to judicial management suggests that even complex and open-ended situations can be handled in a way that complies with familiar, formal procedural standards.

Another concern in public interest cases (as well as with managerial judging) is that if many cases are resolved by negotiated settlement, precedents are not established. The same concern arises if a court proceeds by interim orders, and ultimately provides only a limited reasoned judgment concluding the case, or no judgment at all. This is not necessarily merely judicial laziness. As we saw,

clear that it is ultimately more cost-effective or better serves the poor litigant's interests to dispense too hastily with procedural steps. I have argued elsewhere that insufficient regulation of Indian PIL has likely tended to exclude the poor-Fowkes, supra note 1, at 451-61.

52 See A. Rosencrancz \& S. S. Lélé, 'Supreme Court and India's Forests' Economic and Political Weekly (2 February 2008) 11.

53 Chandra, supra note 7. 
the open-endedness of public interest cases can resist the sort of factual and legal capturing required to write a judgment.

We might learn here from the Colombian tutela system. The tutela is a formal rights-protecting procedure, with a strict time limit by when a judgment must be issued. The process is rapid and the argument not necessarily very detailed or comprehensive. However, the Constitutional Court reviews all tutela decisions. It selects those it considers necessary to correct or pertinent for the development of its own case law, and issues a judgment in those cases ${ }^{54}$ The effect is to separate the business of finding a solution to the case, done by the lower court, from (most of) the business of articulating law, done by the Constitutional Court, after the fact, in notable cases only.

These are merely two suggestions of the sorts of formal devices that can added to the toolkit of the managerial judge. They offer illustrations of the kind of proceduralisation that I argue is needed in order to safeguard the substantive goods protected by traditional procedures and processes, while rejecting the chauvinistic view that these traditional structures alone are adequate to deal with the realities of modern public interest litigation.

\section{Conclusion}

It is too simple to respond to the challenges of procedure in public interest cases by merely advocating substance over form. That says no more than that we should avoid procedure for procedure's sake. While true, it tells us little about whether and when substantive ends are better served by eliminating procedural rules, or insisting upon them, or re-designing them. The same goes for arguments that one particular kind of procedure fits public interest litigation. In fact, such litigation takes multiple forms and its procedural needs vary with the nature of the problem and the attitude of the parties. Creativity is vital to ensure that litigation serves the public interest as much as possible, but based on the challenges described in this paper, we should take seriously the possibility that what serves the public interest might be more procedure, not less. If we do, the global growth of public interest litigation means we will have rich comparative resources to draw upon.

54 Cepeda-Espinosa, supra note 17, at 552-4 (emphasis added). See also Eslava, supra note 20, at 204. 